\title{
The Outcome of Politically Connected Boards on Commercial Bank Performance in Malaysia
}

\author{
Wai-Ching Poon ${ }^{1}$, Angeline Kiew-Heong Yap ${ }^{2} \&$ Teck-Heang Lee ${ }^{2}$ \\ ${ }^{1}$ School of Business, Department of Economics, Monash University Sunway Campus, Jalan Lagoon Selatan, \\ Bandar Sunway, Selangor, Malaysia \\ ${ }^{2}$ Department of Business Studies, Help University, Kompleks Pejabat Damansara, Jalan Dungun, Kuala Lumpur, \\ Malaysia \\ Correspondence: Wai-Ching Poon, School of Business, Department of Economics, Monash University Sunway \\ Campus, Jalan Lagoon Selatan, Bandar Sunway, Selangor 56150, Malaysia. E-mail: \\ Poon.wai.ching@monash.edu
}

Received: November 2, 2012

Accepted: November 26, $2012 \quad$ Online Published: December 12, 2012

doi:10.5539/mas.v7n1p35

URL: http://dx.doi.org/10.5539/mas.v7n1p35

\begin{abstract}
This study draws on upper echelon theory (Hambrick \& Mason, 1984) to examine whether the demographic characteristics of politically connected board members affect commercial bank performance in Malaysia. Interaction effect between age, ethnicity, and the political connections of board directors demonstrates that commercial bank performance depends on the presence of non-ethnic minority elder directors who have political connections with higher government authorities. The findings have important implications for corporate governance in commercial banking sectors in Malaysia. Although bank performances are impressive, the valuable human capital resources of board members who have diverse skills and backgrounds remain underutilized. Improving corporate governance performance through better use of human capital resources is of paramount importance for an effective business strategy that facilitates creativity and innovation. Government-Linked Companies (GLCs) should reengineer strategies to support the private sector, instead of crowding out private investment.
\end{abstract}

Keywords: Malaysia, board characteristic, firm performance, politically connected, commercial banks

JEL Classifications: L25, M21

\section{Introduction}

The association between the board of directors and firm performance is not easy to explain using a single governance theory (Nicholson \& Kiel, 2007) (Note 1). Hambrick and Mason's (1984) upper echelons theory has drawn on the disciplines of organizational behaviour and strategic management. The assertion of upper echelons theory identifies observable demographic characteristics, experiences, values, personalities, or strategic behaviours that influence management's value-added decision making styles, profitability variation and firm performance in response to environmental changes. Using the social identity principle (e.g., attractive-selection-attrition), Tajfel and Turner (1986) and Terjesen et al. (2009) explore how individuals seek to surround themselves in specific groups (so-called "groupthink") who share similar demographic profiles, perceptions and principles, which are then reinforced in intra-group communication. Therefore the portrayer of observable demographic profiles and the compositions of upper echelons (top executives or top management team) are determinants of strategic choices and the firm's performance outcomes (see Bantel \& Jackson, 1989; Boeker, 1997).

Diverse human capital (Carter et al., 2010), valuable resources and knowledge of board of directors (Hillman et al., 2000; Jackling \& Johl, 2009) affect board performance. Within the context of corporate governance, firms act as a socially cohesive group (Westphal \& Zajac, 1995) to channel the human capital (Kresner, 1988) and social capital (Pfeffer \& Salancik, 1978) of board directors to facilitate advice, information, legitimacy, communication, and power sharing. Demographic diversity may affect how boards govern their firms, and may influence group decisions. We believe that board diversity increases creativity and innovation, produces a more effective problem-solving approach, enhances the effectiveness of corporate leadership, and promotes more effective global 
relationships (Carter et al., 2003), and facilitates information exchange, discussion and group performance (Kang et al., 2007). We argue that resource dependency, which focuses on access to resources and preferential treatment, usually shows a positive sign.

Political connections are highly relevant in emerging markets. Malaysia is an appealing setting in this study for various reasons. It is a multi-ethnic and cultural country with concentration of ownership in the hands of a few politically connected Government-Linked Companies (GLCs). Ownership of Public-Listed Companies (PLCs) is identifiable along ethnic lines (Yatim et al., 2006). There are three main indigenous groups in Malaysia, namely Malays (Bumiputras), Chinese, and Indians. As of the 2010 census, the population of Malaysia was 28.3 million, and of that number, $50.4 \%$ were Malays, $24.6 \%$ were Chinese, $7 \%$ were Indians, and the remaining $18 \%$ were other natives. Each ethnic group differs economically, culturally and socially. The diverse nature of Malaysian society has become a competitive advantage for many Malaysian firms. The issues of sustainability and inter-generational equity are of great concern in order to achieve the Malaysian government's vision to achieve developed nation status by 2020 . We argue that demographic incidents of shareholder activism significantly impact politically connected directors' decisions that ultimately affect commercial bank performance. To what extent demographic diversities of politically connected directors influence the performance of the firm, both observable demographic diversity (e.g., age, ethnicity and qualification) and non-observable cognitive diversity (e.g., education, experience, knowledge, values, perception, affection and personality characteristics), is the focus of our interest.

We have selected commercial banks in this study due to differences in the regulatory requirements by the Bank Negara Malaysia (BNM, the Central Bank of Malaysia). Within the context of the commercial bank industry (Note 2), incidents of shareholder activism by local institutional shareholders often take place. If the government has a direct controlling stake in firm X, this allows them to appoint the Board of Directors (BOD) in firm X. Consequently the politic-based BOD of this firm may react in favour of the objectives of government policy and may distinctively influence the firms' performance. For instance, Employees Provident Funds (EPF, the government agency social security and pension funds), and Permodalan Nasional Berhad (PNB, the government's national capital corporation) held $18.58 \%{ }^{2}$ direct control of the market in the year 2009 in Malayan Banking Berhad (MBB, the largest local financial group), with EPF: $11.95 \%$ and PNB: $6.63 \%$ stakes. There were also substantial indirect stake controls of $50.38 \%$ by Skim Amanah Saham Bumiputra (ASB, one of the government supported Bumiputra agencies) in MBB. This controlling stake exacerbated the crowding out effect and further aggravated the voting rights of minority investors. It may bring some destructive outcomes in the long term, and threaten moving towards nationalization instead of internationalization. Therefore, a study that focuses on the dark side of political connections, emphasizing over-embeddedness and subjective shareholder expropriation is of value.

Studies of the composition of boards using upper echelon theory in the commercial banking sector have not received much attention. This study sheds light on the performance of commercial banks' by examining the demographic diversity of the politically connected upper echelon BODs within the "groupthink". We use a fixed effect panel approach from 2000-2009 and test a lag effect on firm performance that is uncommon in past studies. Results reveal a positive association between age, size of ethnic minority, qualification (the observable demographic diversity), and experience (the non-observable cognitive diversity) of the politically connected directors on firm performance. Interaction effects show that performance gains are greater for elder politically connected non-ethnic minority directors. This paper shows that the independence of politically connected directors on decision making has been compromised. The contribution of this study is to expand the relationship between political connectedness of the governance structures among Malaysian firms, their upper echelons characteristics, and firm performance to address the corporate governance challenges as important drivers for decision making in the context of multi-ethnicity and cultural emerging economy.

The remainder of this study is organized as follows. The second section provides the applicable theories and hypotheses on the relation between board diversity and performance of the firm. The third section discusses the research methodology, sample, data and variables, followed by a section on model specification. The fourth section discusses the results. Finally, limitations are identified, and implication and concluding remarks in section 5 .

\section{Literature Review}

\subsection{Politically Connected Directors}

A politically connected firm could be a group of large shareholders, such as the CEO, president, vice president, chairman or secretary, who control at least 10 percent of voting share, and are connected with a politician, party, 
minister, or Parliament member (Faccio, 2006). The extant literature documents an association between politically connected firms and Malay ownership corporations (Faccio, 2006; Fraser et al., 2006; Gomez \& Jomo, 2002; Gul, 2006; Johnson \& Mitton, 2003), but opinions about the link between political connections and firm performance have been mixed. Some studies found a positive and significant relationship i) between Malaysian firm leverage and political patronage (e.g., Fraser et al., 2006), and ii) between politically connected firms and firm performance (e.g., Fisman, 2001); while others form a different conclusion (e.g., Fan et al., 2007; Chizema \& Kim, 2010).

Empirical evidence has proved that a bank with politically connected high-ranking officials enrich the business conditions by permeating many barriers (Baum et al., 2008). Politically connected firms receive preferential treatment from government in the form of cheaper sources of funding, favourable tax treatment and access to restricted licenses (Mohamad et al., 2007; Niessen \& Ruenzi, 2010). Since the implementation of New Economic Policy in 1970, the non-Bumiputra businessmen have actively solicited and developed ties with politicians or other special interest groups to influence the allocation of financing (Johnson \& Mitton, 2003) and to extract rents from government (Olson, 1982). Banks with affiliated political entity connections may obtain a licence to carry out transactions for governmental bodies and public authorities at rents set below-market-rate loans. Politically well-connected firms enjoy insider governmental informational advantage and find it relatively easier to win tenders for privatization projects and handling rights for the transactions of governmental institutions that likely increase the profitability of the connectedness firms (Faccio, 2006; Fisman, 2001; Roberts, 1990). Therefore, we hypothesize that:

Hypothesis 1: Having a higher percentage of politically connected directors on board is positively related to bank performance, all else being constant.

Johnson and Mitton (2003) found capital control in September 1998 primarily benefited firms with strong ties to the Malaysian Former Prime Minister. Furthermore, some evidence has suggested that politically connected firms were more likely to be rescued from financial turmoil than non-connected peers (Johnson \& Mitton, 2003; Faccio, 2006). However there were adverse effects on politically connected firms at the early stage of the financial crisis when government cut the subsidies (Johnson \& Mitton, 2003). Furthermore, Mitchell and Joseph (2010) also found that politically connected financial firms performed poorer after the removal of capital controls. The firms of politically connected directors performed poorly due to low financial transparency (Bushman et al., 2004), low professionalism and weak governance (Fan et al., 2007), and incompetent operation as the result of cronyism (Gul, 2006). These findings imply that politically connected firms have a higher probability of receiving government bailouts (Faccio et al., 2006). Therefore, we posit that:

Hypothesis 2: Firms that have had high levels of political-connectedness over the later five years performed poorer than the previous years, all else being constant.

\subsection{Age of Directors}

The age and tenure of the directors "may determine his or her effectiveness in managing the firms" (Cornett et al., 2008, p.360). Alderfer (1986) argues that top board members with little experience may limit the effectiveness of firm, as it takes time to gain an in-depth knowledge of the firm and suggests that the more senior (or the longer the tenure of) the directors, the more likely their knowledge of the industry enhance firm performance. Age diversity of board members may be considered from various perspectives. Kang et al. (2007) believe that young board members are more energetic and are therefore more likely to aim for a successful future; middle board members are suitable to hold important positions in companies because they have the ability to integrate new ideas and confidence when making decisions; and senior board members can share their wisdom by giving valuable experience to management and evaluating decisions more accurately. These studies suggest the more senior the board members and the deeper the knowledge of the firms, the better the firm's performance, and hence a senior politically connected director may positively impact firm performance. We also examine the interaction term to test whether bank performance changes for elder politically connected directors. Based on these arguments, we posit that:

Hypothesis 3: The age of directors is positively related to bank performance, all else being constant.

Hypothesis 4: The elderly politically connected directors are positively associated with firm performance, all else being constant.

\subsection{Ethnicity of Directors}

Theories from interdisciplinary sources provide a relationship between the ethnic board diversity and firm performance. However, the empirical evidence on this link is mixed. Haniffa and Cooke (2002) examine the 
relationship between board composition, culture and voluntary disclosure in Malaysia and conclude that Malays are less professional and secretive, and more uniform and conservative in providing disclosures, when compared to Chinese. In contrast, Ramasamy et al. (2007) claim that Malay CEOs showed higher corporate social performance than Chinese CEOs. Carter et al. (2010) examines the relationship between ethnic minority directors in a sample of U.S. boards and firm performance using fixed effect single regression equation, and they find evidence of a positive and significant relationship between the number of ethnic minority on board and return-on-asset (ROA), but no significant relationship is found between ethnic minority director and financial performance. Nevertheless, Erhardt et al. (2003) reveal a significant positive relationship between ethnic minority on both ROA and return-on-equity (ROE) for U.S. firms. Carter et al. (2003) also find a positive and significant relationship between ethnic minority directors on the board and Tobin's $Q$. Zahra and Stanton (1988), however, reveal no relationship between ethnic minority on the board and firm performance for U.S. firms. Based on Carter et al.'s (2010) and Adams and Ferreira's (2009) conjectures, we argue that ethnic minorities promote board independence because a board which has a diverse ethnicity background might be a more active board in considering issues that are not considered by a homogeneously composed board. We extend these studies by using an interaction term to examine whether bank performance changes for the elderly, ethnic minority directors with political connections. Therefore, we state the following hypotheses:

Hypothesis 5: The number of ethnic minority directors on the board is positively associated with bank performance, ceteris paribus.

Hypothesis 6: The elderly politically connected ethnic minority directors change firm performance, all else being constant.

\subsection{Qualifications of Directors}

The Malaysian Code on Corporate Governance (MCCG) (Revised, 2007, p.11, Note 3) recommends that all directors should be equipped with talent, proficiency, and know-how to demonstrate the credibility and accountability of the management team and to promote the corporate image (Haniffa \& Cooke, 2002). Higher education of top management directors in organizational contexts is positively related to receptivity to innovation, creativity, and better strategic decision making (Bantel, 1993; Becker, 1970). Therefore innovation has become a key firm strategy to gain competitive advantage (Hitt et al., 1996) and the qualifications of directors are positively related to firm performance (Morbey, 1988). This relationship suggests that education level and a diverse functional background are positively related to organizational performance (Bantel, 1993; Haniffa \& Cooke, 2002), especially in business-related background such as in Economics, Law, Marketing, Accounting, Management, or Finance. In addition, Gray (1988) and Wallace and Cooke (1990) suggest that higher education level may increase demand for political awareness and corporate accountability. Hence, less qualified directors are possibly less effective than directors with business qualifications (Ferreira, 2009). Drawing on this strand, we put forward the seventh hypothesis:

Hypothesis 7: The qualification of directors with business backgrounds increases bank performance, all else being constant.

\subsection{Experience}

The "groupthink" cohort is a group of top managerial teams who have some relevant data in common such as socioeconomic background, employment and industry, societal experience, functional track, and training, and have been imprinted on its members and shaped their values and perceptions. While directors are chosen based on "the old boy" network or "people like us", they may have their own priorities in decision making, but the politically connected directors have to support the agenda politically if the director perceives his adherence to the continued of directorship tenure with a firm. It is generally believed that homogeneous managerial teams, manifested as cohesiveness and insularity, will make strategic decisions quicker than heterogeneous teams (Hambrick \& Mason, 1984). Janis (1972), however, argues that homogeneity leads to inferior decision making (cited in Hambrick \& Mason, 1984). In a stable environment or routine situation, problem solving is best handled for a homogeneous group, but in a chaotic environment, problem solving is best managed by a heterogeneous group since diversity of skill allows more airing of alternatives (Filley et al., 1976). Therefore, the following hypothesis is posited:

Hypothesis 8: The degree of peripheral-function experience of directors is positively related to the firm's performance, all else being constant. 


\section{Sample, Variables and Model}

\subsection{Sample and Variables}

The sample consisted of an unbalanced panel of all post-merged domestic commercial banks in Malaysia from 2000-2009 (Note 4). Data was extracted from the companies' websites, companies' Annual Reports, and Bankscope. Panel data analysis was employed to avoid unobservable heterogeneity problems in empirical analyses.

Dependent Variable. We measured firm performance using ROE, a commonly used accounting-based measure of firm performance. Following Fich and Shivdasani (2006), we did not use Tobin's $Q$ because if financial or liquidity constraints cause some firms to under invest, the potential value of unexploited investments may lead to a high marginal Tobin's $Q$. If underinvestment is pervasive, formulation would erroneously treat a high market-to-book ratio, which indicates good governance. We obtained the data on ROE from Bankscope.

Explanatory variables. We define politically connected directors (POL) as the percentage of directors serving as current or former members of a political party, or current or former delegates from the ruling government (Fan et al., 2007; Niessen \& Ruenzi, 2010). Alternately POL could be defined as informal ties between Malaysian politicians and firms run by Malay, Chinese and Indian (Gul, 2006). We measured age (AGE) as tenure in years held by directors. Director age captures the level of expertise built up by the top executive regarding the organization (Alderfer, 1986; Cornett et al., 2008). We expected that senior or longer-tenured directors were less likely to adversely affected performance. Ethnic minority (EM) was measured using the percentage of minority directors on the board (i.e., the Chinese and Indian), while qualification (QUA) measures the percentage of directors with qualifications in business backgrounds (i.e. either in Economics, Law, Marketing, Accounting, Management, or Finance). Experience (EXP) measures the percentage of directors who have experience in the banking industry. To allow for the possibility of partial adjustment to changes in other variables, we included a lagged dependent variable in the performance equation. The one-year lagged firm performance $[\operatorname{ROE}(-1)]$ was employed as stakeholders use previous year firm performance to estimate future performance. It is expected that higher value creation may lead them to expect satisfaction of their interests (Delgado-Garcia et al., 2010). Following Bhagat and Bolton (2008), we used the lagged-one value of ROE as an instrument in our estimations, but we lost data due to the one-year lag. To measure whether there was an association between age, political-connected directors and firm's performance, an interaction term POL*AGE was tested. To measure whether there was an association between age, ethnic minority and political-connected director on the firm's performance, another interaction term $\mathrm{POL}^{*} \mathrm{AGE} * \mathrm{EM}$ was used. Other interaction terms, such as POL*AGE*EXP and POL*AGE*QUA, were also tested, but results were insignificant (results are not reported here).

Control variables. We controlled for firm and director characteristics through firm fixed effects regression methods. The effects of size were controlled for using the natural log of total assets, as it is related to market returns (Fama \& French, 1992). We measured firm size using a natural log of the total assets of the firm. We controlled for board size, measured as the natural log of the number of directors elected on the board. Study considering the effect of board size and financial performance has developed contradictory arguments. Past studies have predicted a positive relation between board size and financial performance (e.g. Dalton et al., 1998; Forbes \& Milliken, 1999; Jackling \& Johl, 2009). Proponents of this view argue that larger boards provide a larger pool of information, and greater depth of intellectual knowledge may improve the quality of strategic decisions that in turn translate into better performance. While larger firms are argued to have better corporate performance, smaller firms are expected to be less controlled in the distribution of firm value (Delgado-Garcia et al., 2010), thus reducing firm performance. Nonetheless, evidence supports the assertion that larger boards encumber communication, coordination and eventually influence the decision-making competencies of the board (Cornett et al., 2008; Jensen, 1993), and smaller boards are more effective monitors than large boards (Yermack, 1996), suggesting that board size is inversely related to performance. Firm performance may drop as firms grow older (Loderer \& Waelchli, 2010) and older firms tend to be larger after merger and acquisition; takeover hazards could increase with firm age, while firm size and age are negatively related to takeover hazard (Palepu, 1986). Therefore we controlled for firm age, measured as the number of years since the firm's first incorporation. The fiscal year-end was controlled for using a dummy variable, with a value of 1 for firms with a 31 December fiscal year-end and zero otherwise (Gul, 2006). Most firms in the sample had a December year-end and all commercial banks had been audited by large audit firms. 


\subsection{Model Specification}

The empirical specification aims to explain the pace in commercial banks' performance using a wider demographic board characteristic. The regression used for testing was as follows:

$$
\begin{aligned}
& P E R F_{i t}=\beta_{0}+\beta_{1} P O L_{i t}+\beta_{2} A G E_{i t}+\beta_{3} E M_{i t}+\beta_{4} Q U A_{i t}+\beta_{5} E X P_{i t}+\beta_{6} P E R F_{i t-1}+ \\
& \beta_{7} P O L^{*} A G E+\beta_{8} P O L^{*} A G E^{*} E M+\beta_{9} F S_{i t}+\beta_{10} B S_{i t}+\beta_{11} F A_{i t}+\beta_{12} F Y_{i t}+\varepsilon_{i t}
\end{aligned}
$$

where $i$ equals each firm, $t$ equals time, and $\varepsilon_{i t}$ is the random error for each observation, which is independent and identically distributed with mean zero and variance $\sigma^{2}$. PERF is the financial performance of the firm measured by commonly used ROE in governance; $P O L$ is the percentage of political connected directors in the board; $A G E$ is the average age of the director; $E M$ is a measure of percentage of ethnic minority on board, i.e., total number of Chinese and Indian directors on the board; $Q U A$ is the percentage of qualified directors; $P E R F_{i t-1}$ is the lagged value of ROE; EXP is the percentage of directors with prior experience in banking sector; $P O L^{*} A G E$ and $P O L^{*} A G E^{*} E M$ are two interaction terms; $F S$ is firm size, as the natural logarithm of the total assets; $B S$ is board size, measured as the natural logarithm of the number of directors on the board; $F A$ is firm age, measured as the number of years since its operation; $F Y$ is the fiscal year, as a dummy variable of 1 if financial ended 31 December, zero otherwise.

\subsection{Panel Regression Method}

A linear model of Equation (1) was estimated on a pooled data sample from 2000-2009 with a constant using fixed effect model estimation using Eview software. The general panel model is written as follows:

$$
P E R F_{i t}=\mu+\beta X_{i t}+\eta_{i}+v_{t}+\varepsilon_{i t} \quad i=1, \ldots, 9 ; t=1, \ldots, 10
$$

where $P E R F_{i t}$ denotes the dependent variable $\left(R O E_{i t}\right)$ for country $i$ at period $t, \beta$ is $k X_{i}$ coefficient vector, and $X_{i t}$ is the $i$-th observation on the $k$ number of explanatory variables $\left[k=12\right.$, see Eq.(1)]. The term $\eta_{i}$ is the cross-sectional unit residual, and the term $v_{t}$ is the unobservable time specific residual to account for firm effect and period effect, respectively. The term $\varepsilon_{i t}$ is the usual error term after removing individual and period effects. These residuals are components of the error term from Equation (1) where $e_{i t}=\eta_{i}+v_{t}+\varepsilon_{i t}$.

Panel regression offers flexibility in modelling heterogeneity in country-specific behaviour, and temporal changes in the country's macroeconomic condition. Pooling both time series and cross-section data provides more information, greater variation, less collinearity, greater degree of freedom and more efficiency (Gujarati \& Porter, 2009). Fixed-effects models are not without their disadvantages. The constant covariates within individuals cannot be measured in this setting. The fixed effects model allows the unobserved firm effects to be correlated with the deterministic variables. If there is a correlation between the fixed effects and the determinants, the random effects model is preferred. The variance component of the dependent variable can be decomposed into:

$$
\sigma_{y}^{2}=\sigma_{\eta}^{2}+\sigma_{v}^{2}+\sigma_{\varepsilon}^{2}
$$

If $\sigma_{\eta}^{2}$ and $\sigma_{v}^{2}$ are zero, Equation (2) is merely a simple pooled regression (with no firm or period effects). If the firm and period effects are insignificant, both $\eta_{i}$ and $v_{t}$ are zero; in this case OLS provides consistent and efficient estimates for both $\mu$ and $\beta$.

\section{Results and Discussion}

\subsection{Descriptive Statistics and Correlation Matrix}

The Malaysian BODs in the commercial banking sector comprised of 6-15 directors, headed by an independent male "chairperson" and included not more than three female directors. The mean age of BOD is 58.99. Table 1 reports descriptive statistics for all variables. The measures of firm performance indicate that the firms were on average financially sound over the 10 years period. The log of return of equity (ROE) is 14.54 , which suggests the net income was higher than the book value of total equity of the firm. The average number of ethnic minority directors (EM) on board was $44.89 \%$, with $22.34 \%$ being politically connected directors (POL), $63.77 \%$ being directors with qualifications (QUA) in business, and $70.76 \%$ of the directors having background experience (EXP) in the banking industry over the sample period. For $78 \%$ of the sample firms the fiscal year ended on December 31. The log of the total assets of the firms (FS) is 10.83, with a board size (BS) of 2.29. Table 2 provides the bivariate correlation matrix for variables. The correlation coefficients between the measures of performance and board characteristic are within the acceptable ranged from 0.0008 and 0.6492 . These coefficients confirm the choice of both deterministic variables and instruments. We found an inverse relationship for the percentages of ethnic minority and ROE. 


\subsection{Unit Root Tests}

Augmented Dickey Fuller (ADF) - Fisher chi-square test, PP Fisher, and Breitung t-stat unit root tests were employed to examine stationarity of the series. The results of the unit root test are reported in Table 3 . Results reveal that all series are $I(1)$ variables, and the unit root test shows that on average pooled data of all variables are stationary at first difference.

Table 1. Summary statistics, annual data (2000-2009)

\begin{tabular}{|c|c|c|c|c|c|}
\hline Variable & Definitions and Unit of measurement & Mean & S.D & Min & Max \\
\hline ROE & The log of total income divided by total equity. & 14.54 & 11.46 & -63.02 & 43.88 \\
\hline POL & Number of political connected directors (\%) & 22.34 & 15.74 & 0.00 & 83.33 \\
\hline AGE & $\begin{array}{l}\text { Average age of the director }=\text { Sum of the ages of all directors } \\
\text { divided by the total number of directors (Year) }\end{array}$ & 58.99 & 4.04 & 50 & 67.30 \\
\hline EM & $\begin{array}{l}\text { Total number of minority (Chinese and Indian, i.e., } \\
\text { non-Bumiputra) directors on the board (\%) }\end{array}$ & 44.89 & 25.70 & 0.00 & 90.91 \\
\hline QUA & $\begin{array}{l}\text { Total number of directors with qualification either in Law, } \\
\text { Business and Management, or Economics (\%) }\end{array}$ & 63.77 & 26.36 & 12.50 & 100.00 \\
\hline EXP & $\begin{array}{l}\text { Number of directors who have background experience in } \\
\text { banking sector }(\%)\end{array}$ & 70.76 & 36.72 & 0 & 100.00 \\
\hline FS & Firm size - The natural log of the total assets of the company. & 10.83 & 0.78 & 9.12 & 12.38 \\
\hline BS & $\begin{array}{l}\text { Board size - The natural log of total number of directors on } \\
\text { the board. }\end{array}$ & 2.289 & 0.20 & 1.79 & 2.71 \\
\hline FA & $\begin{array}{l}\text { Firm age - The natural log of the number of years since its } \\
\text { operation. }\end{array}$ & 21.80 & 19.45 & 3.77 & 48.55 \\
\hline FY & $\begin{array}{l}\text { Fiscal year as indicator variable, } 1 \text { for fiscal year ended } 31 \\
\text { December; } 0 \text { otherwise }\end{array}$ & 0.778 & 0.42 & 0 & 1.00 \\
\hline
\end{tabular}

Table 2. Correlations matrix

\begin{tabular}{lllllllllll}
\hline & ROE & AGE & POL & EM & QUA & EXP & FS & BS & FA & FY \\
\hline ROE & 1.0000 & & & & & & & & & \\
AGE & 0.0215 & 1.0000 & & & & & & & & \\
POL & -0.0541 & 0.3794 & 1.0000 & & & & & & & \\
EM & -0.0449 & -0.4017 & 0.0008 & 1.0000 & & & & & & \\
QUA & 0.2478 & 0.0357 & -0.2519 & 0.0608 & 1.0000 & & & & & \\
EXP & 0.2047 & -0.0549 & -0.0638 & 0.1447 & 0.2774 & 1.0000 & & & & \\
FS & 0.1890 & 0.5189 & -0.0196 & -0.3800 & 0.5154 & 0.1606 & 1.0000 & & & \\
BS & 0.0999 & 0.0149 & -0.0364 & -0.0795 & -0.1696 & -0.209 & 0.1381 & 1.0000 & & \\
FA & 0.0702 & 0.0710 & 0.0550 & 0.2199 & 0.6492 & 0.3243 & 0.5181 & -0.2980 & 1.0000 & \\
FY & -0.2306 & 0.2019 & 0.4316 & 0.0800 & -0.3702 & -0.2135 & -0.3123 & -0.1151 & -0.3699 & 1.0000 \\
\hline
\end{tabular}

Notes: The table presents pairwise correlation coefficients between variables. Chinese and Indian are ethnic minorities. 
Table 3. Results of panel data regression model

\begin{tabular}{|c|c|c|c|c|c|c|}
\hline & \multicolumn{2}{|c|}{ ADF-Fisher Chi-square } & \multicolumn{2}{|c|}{ PP-Fisher } & \multicolumn{2}{|c|}{ Breitung t-stat } \\
\hline & $\begin{array}{l}\text { Level } \\
\text { Constant } \\
\text { with trend }\end{array}$ & $\begin{array}{l}\text { First } \\
\text { difference } \\
\text { Constant } \\
\text { with trend }\end{array}$ & $\begin{array}{l}\text { Level } \\
\text { Constant } \\
\text { with trend }\end{array}$ & $\begin{array}{l}\text { First } \\
\text { difference } \\
\text { Constant } \\
\text { with trend }\end{array}$ & $\begin{array}{l}\text { Level } \\
\text { Constant } \\
\text { with trend }\end{array}$ & $\begin{array}{l}\text { First } \\
\text { difference } \\
\text { Constant } \\
\text { with trend }\end{array}$ \\
\hline AGE & 16.302 & $26.891 * *$ & 16.932 & $55.69 * * *$ & -0.9574 & -1.257 \\
\hline EM & 12.054 & 19.75 & $44.843 * * *$ & $79.18 * * *$ & 0.9741 & $-1.788 * *$ \\
\hline QUA & 8.3521 & 18.52 & 19.611 & $50.53 * * *$ & 0.1272 & $-2.118 * *$ \\
\hline POL & 8.8811 & 15.52 & 14.543 & $44.99 * * *$ & 2.7084 & $-2.347 * * *$ \\
\hline ROE & 17.974 & $41.213 * * *$ & 21.764 & $77.57 * * *$ & 0.4224 & -0.299 \\
\hline ROE(-1) & 18.007 & $41.808^{* * *}$ & 26.495 & $74.97 * * *$ & 0.5382 & -0.165 \\
\hline EXP & 8.9240 & $32.49 * *$ & $23.662 *$ & $51.67 * * *$ & -0.3945 & -1.225 \\
\hline FS & 8.248 & 19.416 & 15.108 & $51.52 * * *$ & -0.0436 & $-2.629 * * *$ \\
\hline BS & 11.554 & $26.658 * *$ & 10.360 & $95.33 * * *$ & -1.1116 & $-1.5405^{*}$ \\
\hline FA & $18.420 * * *$ & $153.39 * * *$ & $165.78 * * *$ & $151.91 * * *$ & 4.323 & $-4.933 * * *$ \\
\hline
\end{tabular}

Notes: AGE is the average age of the director, EM is the total number of minority (Chinese and Indian, i.e., non-Bumiputra) directors on the board (\%), QUA is Total number of directors with qualification either in Law, Business and Management, or Economics (\%), POL is the number of political connected directors (\%), ROE is the natural $\log$ of return to equity, EXP is Number of directors who have background experience in banking sector (\%), FS is firm size, measured as the natural log of the total assets of the company, BS is board size, measured as the natural log of total number of directors on the board, FA is firm age, measured as the natural log of the number of years since its operation. The null hypothesis is that the series are non-stationary or contains a unit root. The rejection of null hypothesis for ADF test is based on the MacKinnon critical values. Lag length selection is based on automatic selection: SIC. Spectral estimation is based on Barlett Kernel, Bandwidth selection is based on automatic Newey-West. *, **, and *** denote the rejection of the null hypothesis of non-stationary at $\mathrm{p}<.10, \mathrm{p}<.05$, and $\mathrm{p}<.01$ significance level. Probabilities for Fisher tests are computed using an asymptotic Chi-square distribution. All other tests assume asymptotic normality.

\subsection{Analysis}

Table 4 reports the fixed effect regression models. The association between firm performance and $P O L, A G E$, $E M, Q U A, E X P$ is tested in both Model 1 (with no control variable) and Model 2 (with control variable - FS and BS). By adding two interaction terms to Model 1, the interaction effects are tested in Model 3. In Model 4, we include lag-one firm performance to Model 1 to test the past year effect on today's performance. In Model 5, we test all variables in Model 4 plus one interaction term to test the interaction effect between POL*AGE on firm performance. By including the control variables to Model 5, a robustness test is carried out in Model 7. In Model 6 , we include two interaction terms to test the effects e.g., POL*AGE*EM on firm performance, and lastly the full model is tested in Model 8 (with control variables and interaction terms). The probability of the F-statistic for the overall regression relationship for all independent variables is at least at $\mathrm{p}<.05$, except for Model 7 at $\mathrm{p}<0.1$. Overall, results reveal significant and positive signs in the predicted direction for the coefficients for $P O L$, $A G E, Q U A$, and EXP. The coefficient for $P O L$ is positive and significant for all models at $\mathrm{p}<.05$, thereby providing support for Hypothesis 1. There is evidence suggesting that a higher percentage of politically connected directors on boards enhance bank performance by $3 \%$, holding all other things constant (see Model 8). Therefore having politically connected directors would be an important aspect of corporate performance. This finding implicitly shows that directors representing investors' interests or non-political professionals might obstruct politicians' agendas.

The study reveals age diversity is significant and positively associated with ROE for four out of eight models. This study reveals that senior directors gain more experience and obtain adequate knowledge in banking industry, and thus are more effective in managing the firm. However, these senior directors are compromised due to their political affiliation. Firms with government-linked and politically connected directors need allies on the board to 
reinforce their objectives and policies that ultimately lead to better persuasive governance, increase professionalism and more attractive firm performances. This finding suggests that the more senior the firm's director, the greater experience, wisdom and understanding of the banking industry, and the better the firm performance. This finding provides weak evidence to support Hypothesis 3 that the age of directors is positively associated with bank performance. Therefore our result is consistent with the assertion that age diversity increases creativity and problem-solving capability Cornett et al. (2008) and Kang et al. (2007). Senior directors are more conservative in pursuing a firm's strategies and tend to focus on business activities that yield immediate profits in the short term during their service periods, ultimately improving firm performance (see Cox, 1993; Li et al., 2011; Milliken \& Martins, 1996).

The results show a positive relationship between performance and the qualifications of directors. This finding supports the belief that top management teams who have qualifications in business-related disciplines such as Marketing, Management, Finance, Law or Economics, improved higher banks performance, and therefore supports Hypothesis 7. These qualified directors chose to increase firm performance to promote corporate image, and demonstrate accountability and credibility within the management team. On the other hand, four out of eight models show that directors with relevant business experience are significantly and positively associated with performance, weakly supporting Hypothesis 8 .

Results, however, reveal neither ethnic minority nor past performance significantly impact firm performance. We have no evidence to support the notion that firms with directors predominantly by Chinese and Indian outperform the Bumiputra directors in commercial banking industry. Hence, Hypothesis 5, i.e. the assertion that the number of ethnic minority directors on a board is positively associated with bank performance, is not supported. The nature of the relationship between ethnic minority on the board and firm performance is merely a public policy issue. On the other hand, there is no statistical difference when previous year firm performance is added to Models 4-8. This finding suggests that they are more likely to be under the control of politically connected directors for post-merging banks.

For the control variables, results reveal a positive relationship between performance and firm size at $\mathrm{p}<1$. This finding is consistent with the argument that larger firms are expected to perform better because they are able to diversify their risks (Ghosh, 1998). In addition, directors are closely monitored by more analysts and thus they are under more pressure to perform well (Haniffa \& Hudaib, 2006). However, there is no evidence to support the assertion that larger boards hinder communication, coordination and eventually the performance of the firm.

The coefficient of the interaction term of $P O L^{*} A G E$ is negative and significant (e.g., $\beta=-0.754, \mathrm{p}<.01$ in Model 8). From Equation (1), the significant coefficient of the sum of $\beta_{l}$ and $\beta_{7}$ is 2.311 (3.065-0.754), providing evidence that senior political-connected directors enhance firm performance by approximately $2.3 \%$ compared to non-connected peers (supporting Hypothesis 4). When the ethnic minority factor is taken into account, the significant coefficient for $P O L^{*} A G E^{*} E M(\beta=0.0004, \mathrm{p}<.05)$ of -0.7536 [the sum of $\beta_{7}$ and $\beta_{8}$, i.e., $-0.754+0.0004$ suggests that elderly political-connected ethnic minority director reduces firm performance by $0.75 \%$ (supporting Hypothesis 6 ). This result suggests that the market does react to the ethnic minority factor. In other words, expectations about merger-related gains are greater for senior politically connected non-ethnic minority directors. 
Table 4. Fixed effect regression estimates of the relationship between firm performance and board characteristic

\begin{tabular}{|c|c|c|c|c|c|c|c|c|}
\hline $\begin{array}{l}\text { Independent } \\
\text { variables }\end{array}$ & Model 1 & Model 2 & Model 3 & Model 4 & Model 5 & Model 6 & Model 7 & Model 8 \\
\hline POL & $\begin{array}{l}0.0500 * * \\
(0.016)\end{array}$ & $\begin{array}{l}0.0493 * * * \\
(0.0178)\end{array}$ & $\begin{array}{l}3.4434 * * \\
(1.606)\end{array}$ & $\begin{array}{l}0.0524 * * * \\
(0.018)\end{array}$ & $\begin{array}{l}3.5001 * * \\
(1.506)\end{array}$ & $\begin{array}{l}4.5203 * * \\
(1.738)\end{array}$ & $\begin{array}{l}1.9474 * * \\
(0.940)\end{array}$ & $\begin{array}{l}3.065 * * * \\
(1.030)\end{array}$ \\
\hline AGE & $\begin{array}{l}3.2180 \\
(5.700)\end{array}$ & $\begin{array}{l}4.4042 \\
(6.153)\end{array}$ & $\begin{array}{l}18.738 * * \\
(9.083)\end{array}$ & $\begin{array}{l}1.2558 \\
(6.097)\end{array}$ & $\begin{array}{l}17.527 * \\
(9.196)\end{array}$ & $\begin{array}{l}21.964 * * \\
(9.923)\end{array}$ & $\begin{array}{l}8.1065 \\
(5.892)\end{array}$ & $\begin{array}{l}11.073^{*} \\
(5.772)\end{array}$ \\
\hline EM & $\begin{array}{l}-0.0206 \\
(0.0188)\end{array}$ & $\begin{array}{l}-0.0232 \\
(0.0196)\end{array}$ & $\begin{array}{l}-0.0130 \\
(0.025)\end{array}$ & $\begin{array}{l}0.0007 \\
(0.023)\end{array}$ & $\begin{array}{l}0.0042 \\
(0.022)\end{array}$ & $\begin{array}{l}-0.0205 \\
(0.031)\end{array}$ & $\begin{array}{l}0.0180 * \\
(0.009)\end{array}$ & $\begin{array}{l}-0.0113 \\
(0.015)\end{array}$ \\
\hline QUA & $\begin{array}{l}0.0404^{* *} \\
(0.016)\end{array}$ & $\begin{array}{l}0.0415^{* *} \\
(0.017)\end{array}$ & $\begin{array}{l}0.0461 * * * \\
(0.015)\end{array}$ & $\begin{array}{l}0.0301 \\
(0.019)\end{array}$ & $\begin{array}{l}0.0357^{*} \\
(0.019)\end{array}$ & $\begin{array}{l}0.0351^{*} \\
(0.019)\end{array}$ & $\begin{array}{l}0.0236^{* *} \\
(0.011)\end{array}$ & $\begin{array}{l}0.019 * \\
(0.009)\end{array}$ \\
\hline EXP & $\begin{array}{l}0.0070 \\
(0.006)\end{array}$ & $\begin{array}{l}0.0058 \\
(0.007)\end{array}$ & $\begin{array}{l}0.0107 \\
(0.006)\end{array}$ & $\begin{array}{l}0.0129 \\
(0.0083)\end{array}$ & $\begin{array}{l}0.0169 * * \\
(0.008)\end{array}$ & $\begin{array}{l}0.0170^{* *} \\
(0.008)\end{array}$ & $\begin{array}{l}0.0140 * * \\
(0.006)\end{array}$ & $\begin{array}{l}0.0166^{* * *} \\
(0.005)\end{array}$ \\
\hline $\operatorname{ROE}(-1)$ & & & & $\begin{array}{l}-0.0896 \\
(0.1298) \\
\end{array}$ & $\begin{array}{l}-0.1338 \\
(0.125) \\
\end{array}$ & $\begin{array}{l}-0.0692 \\
(0.137) \\
\end{array}$ & $\begin{array}{l}-0.1012 \\
(0.112) \\
\end{array}$ & $\begin{array}{l}0.0341 \\
(0 . .105)\end{array}$ \\
\hline POL*AGE & & & $\begin{array}{l}-0.8297 * * \\
(0.3960)\end{array}$ & & $\begin{array}{l}-0.8427 * * \\
(0.3681)\end{array}$ & $\begin{array}{l}-1.1015^{* *} \\
(0.42897)\end{array}$ & $\begin{array}{l}-0.4680 * * \\
(0.2288)\end{array}$ & $\begin{array}{l}-0.754 * * * \\
(0.2543)\end{array}$ \\
\hline $\begin{array}{l}\mathrm{POL} * \mathrm{AGE}^{*} \mathrm{E} \\
\mathrm{M}\end{array}$ & & & $\begin{array}{l}-0.00003 \\
(0.0002)\end{array}$ & & & $\begin{array}{l}0.0003 \\
(0.0002)\end{array}$ & & $\begin{array}{l}0.0004 * * \\
(0.0001)\end{array}$ \\
\hline FS & & $\begin{array}{l}-0.7132 \\
(1.2189)\end{array}$ & & & & & $\begin{array}{l}0.7449 \\
(0.5032)\end{array}$ & $\begin{array}{l}0.7518^{*} \\
(0.4313)\end{array}$ \\
\hline BS & & $\begin{array}{l}0.2330 \\
(1.3383)\end{array}$ & & & & & $\begin{array}{l}-0.47318 \\
(1.1498)\end{array}$ & $\begin{array}{l}-0.7817 \\
(1.0392)\end{array}$ \\
\hline FA & & & & & & & $\begin{array}{l}-1.058^{* * *} \\
(0.3330)\end{array}$ & $\begin{array}{l}-1.162 * * * \\
(0.3317)\end{array}$ \\
\hline FY & & & & & & & $\begin{array}{l}-1.247 * * * \\
(0.5196)\end{array}$ & $\begin{array}{l}-1.814 * * * \\
(0.5817)\end{array}$ \\
\hline $\mathrm{C}$ & $\begin{array}{l}-14.3614 \\
(23.07) \\
\end{array}$ & $\begin{array}{l}-11.891 \\
(23.962) \\
\end{array}$ & $\begin{array}{l}-78.370 * * \\
(37.02)\end{array}$ & $\begin{array}{l}-7.0096 \\
(24.66) \\
\end{array}$ & $\begin{array}{l}-74.034 * \\
(37.607) \\
\end{array}$ & $\begin{array}{l}-91.509^{* *} \\
(40.36)\end{array}$ & $\begin{array}{l}-37.945^{*} \\
(22.587) \\
\end{array}$ & $\begin{array}{l}-47.646^{* *} \\
(22.198)\end{array}$ \\
\hline $\begin{array}{l}\text { Cross-section } \\
\text { fixed effects }\end{array}$ & $\sqrt{ }$ & $\sqrt{ }$ & $\sqrt{ }$ & $\sqrt{ }$ & $\sqrt{ }$ & $\sqrt{ }$ & & \\
\hline $\begin{array}{l}\text { Period fixed } \\
\text { effects }\end{array}$ & $\sqrt{ }$ & $\sqrt{ }$ & $\sqrt{ }$ & $\sqrt{ }$ & $\sqrt{ }$ & $\sqrt{ }$ & $\sqrt{ }$ & \\
\hline Observations & 78 & 78 & 78 & 69 & 69 & 69 & 66 & 66 \\
\hline $\begin{array}{l}\text { Number of } \\
\text { cross-sections }\end{array}$ & 9 & 9 & 9 & 9 & 9 & 9 & 9 & 9 \\
\hline $\begin{array}{l}\text { Sample } \\
\text { period }\end{array}$ & 2000-2009 & 2000-2009 & 2000-2009 & 2001-2009 & 2001-2009 & 2001-2009 & 2001-2009 & 2001-2009 \\
\hline $\mathrm{R}^{2}$ & 0.5005 & 0.5038 & 0.5543 & 0.4823 & 0.5363 & 0.5501 & 0.4137 & 0.3517 \\
\hline Adj.R-squared & 0.3007 & 0.2791 & 0.3525 & 0.2348 & 0.2993 & 0.3048 & 0.1716 & 0.2050 \\
\hline F-statistic & $2.5052 * * *$ & $2.2422 * * *$ & $2.7472 * * *$ & $1.9484 * *$ & $2.2633 * * *$ & $2.2423 * * *$ & $1.7087^{*}$ & $2.3970 * *$ \\
\hline
\end{tabular}

Notes: All regressions are estimated using panel least squares. Dependent variable: ROE, the natural log of return to equity. POL is the number of political connected directors (\%), AGE is the average age of the director, 
EM is the total number of minority (Chinese and Indian, i.e., non-Bumiputra) directors on the board (\%), QUA is Total number of directors with qualification either in Law, Business and Management, Economics, and etc. (\%), EXP is Number of directors who have background experience in banking sector (\%), FS is firm size, measured as the natural $\log$ of the total assets of the company, BS is board size, measured as the natural log of total number of directors on the board, FA is firm age, measured as the natural $\log$ of the number of years since its operation, and FY is the Fiscal year as indicator variable, 1 for fiscal year ended 31 December; 0 otherwise. Probability values are based on a t-statistic for a two-tailed test of significance. The first number of each cell is the regression coefficient and figures in the parentheses are standard errors. $\mathrm{R}^{2}$ is the explanatory power of the regressor. ${ }^{*}, * *$ and $* * *$ denotes statistically significance at $\mathrm{p}<10, \mathrm{p}<.05$ and $\mathrm{p}<.01$ level, respectively.

To test whether politically connected firms performed poorer in the later five years, we divided the sample periods into early years (2000-2004), and later years (2005-2009). Year 2004 has been chosen as the cut-off year because this was the last year the $4^{\text {th }}$ prime minister held official position in the government. Results in Table 5 reveal that the mean value for low politically connected firms shows significant improvement in performance during the later years; meanwhile the mean value for high politically connected firm is relatively lower during the later five years. Hence, we conclude that firms that are politically connected performed poorer in the later five years, thereby supporting Hypothesis 2 . These firms performed poorly due to inefficient operation as a result of cronyism and the changing hand among politicians.

Table 5. Mean estimates between political connection and period

\begin{tabular}{lll}
\hline Connection & $\begin{array}{l}\text { Early Years } \\
(2000-2004), \mathrm{N}=45\end{array}$ & $\begin{array}{c}\text { Later Years } \\
(2005-2009), \mathrm{N}=45\end{array}$ \\
\hline Low politically connection, $\mathrm{N}=25$ & 1.5291 & 1.8420 \\
High politically connection, $\mathrm{N}=65$ & 2.2677 & 2.0750 \\
\hline
\end{tabular}

Note: Full sample, $\mathrm{N}=90$. If number of politically connected director on board is less than 10 percent, it is classified as low politically connection, and otherwise. F statistics $=2.888^{* *}, * *$ denotes significant at 5 percent.

\subsection{Endogeneity Test}

The study of the upper echelons board-performance link is plagued with an endogeneity problem, and this problem may bias the results on firm performance. Instances of firms performing well could be due to the political connectedness of the upper-echelons. It could also be due to reputation that these delegates only chose the better performing firms to work for. That is, if the explanatory variable $(\mathrm{X})$ and the error terms were correlated, the OLS estimate would likely be attributed to the $\mathrm{X}$ of some of the variation in the dependent variable that actually comes from the error term. In this paper we deal with this endogeneity problem by examining the issue of whether political connectedness affect firm performance or whether firm performance affects political-connectedness. Therefore, formally testing whether or not these explanatory variables are endogeneous is a matter of pre-requisite. We attempt to control for the possible reverse causality by using a time-lagged approach between politically connectedness and firm performance. Specifically, we use the following simple models to determine whether $x_{\mathrm{ik}}$ in the model is endogenous or, more precisely, whether it is correlated with the error term $u_{\mathrm{i}}$, where $x_{\mathrm{ik}}$ is a $k$-element row vector whose last element, $x_{\mathrm{k}}$.

$$
y_{\mathrm{i}}=x_{\mathrm{i}} \cdot \beta+u_{\mathrm{i}}, x_{\mathrm{ik}}=z_{\mathrm{i}} \cdot+v_{\mathrm{i}}, i=1,2, \ldots n
$$

First we test if beta is equal to zero (it means that $x_{\mathrm{i}}$ has no predictability to $y_{\mathrm{i}}$ ), save its residual as the first error term; and then $\mathrm{X}_{\mathrm{i}, \mathrm{t}}$ is regressed on $\mathrm{X}_{\mathrm{i}, \mathrm{t}-\mathrm{1}}$, again save its residual as the second error term. Finally we test if the first error term is correlated with the second error term. Results reveal that we cannot reject the hypothesis (coefficient $=0.572, t$-stat $=1.070, \mathrm{P}=0.288$ ), which implies that error terms do not correlate to each other. Hence the endogeneity problem has been sorted out.

\section{Discussion, Conclusion and Policy Implication}

This study employs upper echelon theory to examine the impact of governance and demographic characteristics of politically connected board members on firm performance. We investigate the impact of political connections, age, ethnic minority, qualification, and experience of board members on commercial bank performance. Results 
reveal that bank performance of politically connected firms improves compared to the non-connected peers. Overall, we conclude that having a relatively higher number of politically connected directors, qualified senior directors, and peripheral-function experience of directors on the board will lead to higher bank performance, ceteris paribus. Consistent with upper echelon theory, the directors' greater knowledge base, creativity and innovation were a competitive advantage to improve bank performance. Hence, there is a need to legitimise the selection of directors with higher educational qualifications. Furthermore, diverse group dynamics are likely to impact controlling function and minimize potential agency issues (Erhardt et al., 2003). The finding in this study is consistent with the argument by Johnson and Mitton (2003) and Gul (2006). While neither ethnic minority nor past performance significantly impacts firm performance, the interaction effects show that ethnic minority plays a role in determining firm's performance, in which there is a positive association between elder non-ethnic minority politically connected directors and bank performance.

The findings suggest that corporate governance can be improved through better use of the entire aptitude capital of the directors. An interaction term that embraces age, ethnic diversity, and political connections is a good practice and serves as a business strategy for creativity and innovation that could strengthen firm performance. The innovation needed now is not to eliminate the long implanted special connections practices within directors, but we need to delve into how politically connected directors can make a difference to improve firm performance as an injection booster to leap forward onto the next podium of economic growth and position Malaysia to become a high income nation by 2020. The Malaysian government has embraced an entire new paradigm via Economic Transformational Program and New Economic Model, particularly focused on private sector's accessibility to capital to boost and rejuvenate investment, facilitate modern business, encourage competition, and attract foreign direct investment in domestic banking institutions.

The results of this study imply that appropriate human capital for directorship brings positive value-added to boards. Therefore, reengineering GLCs, reenergizing the support to private sector, and creating a competitive domestic economy are of utmost importance. GLCs should engineer socioeconomic change through wealth redistribution, and should not crowd out private investment. Trust is an important element amongst different ethnic groups for fundamental economic network integration. Malaysia's major obstacle is the absence of fairer competition to raise competitiveness within the nation. This lack of fairness has caused difficulty for global foreign investors to invest in the nation. Continuous and significant regulatory framework improvements needs to be embedded into government practice with respect to transparency, non-discrimination, objective-based and performance-based criteria, market-based mechanisms and accountability to reap independence, integrity and soundness of policies and regulations. These informational levels will then be prescribed by mechanisms put in place within the competitive governance and legal environment to ensure rational management decision making processes.

Notwithstanding its contributions, this study has limitations. There are only nine commercial banks in Malaysia in the total population at the time of study, and we have included all nine banks data in this study; this sample remains too small to substantiate claims and may cause firm-specific bias. However the sample is restricted to Malaysian commercial banking industry because other industries have different regulation structures, cultural environments and other factors that may result in different board compositions and firm performances. Future research may undertake gender perspective in multiple directorships to measure firm performance within banking industry. Future study may consider both short- and long-term impact of corporate governance reforms on firm performance.

\section{References}

Adams, R. B., \& Ferreira, D. (2009). Women in the boardroom and their impact on governance and performance. Journal of Financial Economics, 94, 291-309. http://dx.doi.org/10.1016/j.jfineco.2008.10.007

Alderfer, C. P. (1986). The invisible director on corporate boards. Harvard Business Review, 64, 38-52.

Anderson, A., \& Gupta, P. P. (2009). A cross-country comparison of corporate governance and firm performance: Do financial structure and the legal system matter? Journal of Contemporary Accounting and Economics, 5, 61-79. http://dx.doi.org/10.1016/j.jcae.2009.06.002

Bantel, K. (1993). Strategic clarity in banking: Role of top management-team demography. Psychological Reports, 3, 1187-1203. http://dx.doi.org/10.2466/pr0.1993.73.3f.1187

Bantel, K., \& Jackson, S. (1989). Top management and innovations in banking: Does the composition of the top team make a difference? Strategy Management Journal, 10, 107-124. http://dx.doi.org/10.1002/smj.4250100709 
Basel Committee on Banking Supervision. (2005). Enchancing corporate governance for banking organisation. Retrieved from http://www.bis.org/publ/bcbs117.pdf

Basel Committee on Banking Supervision. (2006). Enchancing corporate governance for banking organisation. Retrieved from http://www.bis.org/publ/bcbs122.pdf

Baum, C. F., Caglayan, M., Schäfer, D., \& Talavera, O. (2008). Political patronage in Ukrainian banking. The Economics of Transition, 16, 537-557. http://dx.doi.org/10.1111/j.1468-0351.2008.00331.x

Becker, M. H. (1970). Sociometric location and innovativeness: Reformulation and extension of the diffusion model. American Sociological Review, 35, 267-304. http://dx.doi.org/10.2307/2093205

Berger, A. N., \& Patti, E. B. (2006). Capital structure and firm performance: A new approach to testing agency theory and an application to the banking industry. Journal of Banking and Finance, 30, 1065-1102. http://dx.doi.org/10.1016/j.jbankfin.2005.05.015

Bhagat, S., \& Bolton, B. (2008). Corporate governance and firm performance. Journal of Corporate Finance, 14, 257-273.

Boeker, W. (1997). Strategic change: The influence of managerial characteristics and organizational growth. Academy of Management Journal, 40, 152-170. http://dx.doi.org/10.2307/257024

Bushman, R. M., Piotroski, J. D., \& Smith, A. J. (2004). What determines corporate transparency? Journal of Accounting Research, 42, 207-252. http://dx.doi.org/10.1111/j.1475-679X.2004.00136.x

Carter, D. A., D’Souza, F., Simkins, B. J., \& Simpson, W. G. (2010). The gender and ethnic diversity of US boards and board committees and firm financial performance. Corporate Governance: An International Review, 18, 396-414. http://dx.doi.org/10.1111/j.1467-8683.2010.00809.x

Carter, D. A., Simkins, B. J., \& Simpson, W. G. (2003). Corporate governance, board diversity and firm value. The Financial Review, 38, 33-53. http://dx.doi.org/10.1111/1540-6288.00034

Chizema, A., \& Kim, J. (2010). Outside directors on Korean boards: governance and institutions. Journal of Management Studies, 47, 109-129. http://dx.doi.org/10.1111/j.1467-6486.2009.00868.x

Chong, B. S., Liu, M. H., \& Tan, K. H. (2006). The wealth effect of forced bank mergers and cronyism. Journal of Banking and Finance, 30, 3215-3233. http://dx.doi.org/10.1016/j.jbankfin.2005.12.004

Cornett, M. M., Marcus, A. J., \& Tehranian, H. (2008). Corporate governance and pay-for-performance: the impact of earnings management. Journal of Financial Economics, 87, 357-373. http://dx.doi.org/10.1016/j.jfineco.2007.03.003

Cox, T. H. (1993). Cultural diversity in organisations: Theory, research and practice. San Francisco, CA: Berrett-Koehler.

Dalton, D. R., Daily, C., Ellstrand, A. E., \& Johnson, J. L. (1998). Meta-analytic reviews of board composition, leadership structure and financial performance. Strategic Management Journal, 19, 269-290. http://dx.doi.org/10.1002/(SICI)1097-0266(199803)19:3<269::AID-SMJ950>3.0.CO;2-K

Delgado-Garcia, J. B., de Quevedo-Puente, E., \& de la Fuente-Sabate, J. M. (2010). The impact of ownership structure on corporate reputation: Evidence from Spain. Corporate Governance: An International Review, 18, 540-556. http://dx.doi.org/10.1111/j.1467-8683.2010.00818.x

Erhardt, N. L., Werbel, J. D., \& Shrader, C. B. (2003). Board of director diversity and firm financial performance. Corporate Governance: An International Review, 11, 102-111. http://dx.doi.org/10.1111/1467-8683.00011

Faccio, M. (2006). Politically connected firms. American Economic Review, 96, 369-386. http://dx.doi.org/10.1257/000282806776157704

Fama, E. R., \& French, K. (1992). The cross-section of expected stock returns. Journal of Finance, 47, 427-465. http://dx.doi.org/10.1111/j.1540-6261.1992.tb04398.x

Fan, J. P. H., Wong, T. J., \& Zhang, T. (2007). Politically connected CEOs, corporate governance and post-IPO performance of China's newly partially privatised firms. Journal of Financial Economics, 84, 330-357. http://dx.doi.org/10.1016/j.jfineco.2006.03.008

Ferreira, D. (2009). Chapter 12: Board Diversity. In Anderson, R. and Baker H. K. (Eds.), Corporate Governance: A Synthesis of Theory, Research, and Practice, 225-242. John Wiley and Sons. http://personal.lse.ac.uk/FERREIRD/research.htm 
Fich, E. M., \& Shivdasani, A. (2006). Are busy boards effective monitors?. The Journal of Finance, LXI, 689-724. http://dx.doi.org/10.1111/j.1540-6261.2006.00852.x

Filley, A. C., House, R. J., \& Kerr, S. (1976). Managerial Process and Organizational Behavior. Glenview, Illinois: Scott, Foresman and Company.

Fisman, R. (2001). Estimating the value of political connections. American Economic Review, 91, $1095-1102$. http://dx.doi.org/10.1257/aer.91.4.1095

Forbes, D. P., \& Milliken, F. J. (1999). Cognition and corporate governance: Understanding boards of directors as strategic decision-making groups. Academy of Management Review, 24, 489-505.

Fraser, D. R., Zhang, H., \& Derashid, C. (2006). Capital structure and political patronage: The case of Malaysia. Journal of Banking and Finance, 30, 1291-1308. http://dx.doi.org/10.1016/j.jbankfin.2005.05.008

Ghosh, A. (1998). Does Accounting base performance really improve following corporate acquisitions?. Working Paper, Zickling School of Business, Baruch College, New York, USA.

Gomez, E. T., \& Jomo, K. S. (2002). Malaysia's Political Economy: Politics, patronage and profits (2nd ed.). Cambridge: Cambridge University Press.

Gorton, G., \& Schmid, F. (1999). Corporate governance, ownership dispersion and efficiency: empirical evidence from Austrian cooperative banking. Journal of Corporate Finance, 5, 119-140. http://dx.doi.org/10.1016/S0929-1199(98)00019-4

Gray, S. J. (1988). Towards a theory of cultural influence on the development of Accounting systems internationally. Abacus, 24, 1-15. http://dx.doi.org/10.1111/j.1467-6281.1988.tb00200.x

Gujarati, D. N., \& Porter, D. C. (2009). Basic Econometrics (5th ed.). New York: The McGraw-Hill Companies Inc.

Gul, F. A. (2006). Auditors' response to political connections and cronyism in Malaysia. Journal of Accounting Research, 44, 931-963. http://dx.doi.org/10.1111/j.1475-679X.2006.00220.x

Hambrick, D. C., \& Mason, P. A. (1984). Upper echelons: The organization as a reflection of its top managers. Academy of Management Review, 9, 193-349.

Haniffa, R. M., \& Cooke, T. E. (2002). Culture, corporate governance and disclosure in Malaysian corporations. Abacus, 38, 317-349. http://dx.doi.org/10.1111/1467-6281.00112

Haniffa, R. M., \& Hudaib, M. (2006). Corporate governance structure and performance of Malaysian listed companies. Journal of Business Finance and Accounting, 33, 1034-1062. http://dx.doi.org/10.1111/j.1468-5957.2006.00594.x

Hillman, A. J., Cannella, J. A. A., \& Paetzold, R. L. (2000). The resource dependence role of corporate directors: Strategic adaption of board composition in response to environmental change. Journal of Management Studies, 37, 235-255. http://dx.doi.org/10.1111/1467-6486.00179

Hitt, M. A., Hoskisson, R. E., Johnson, R. A., \& Moesel, D. D. (1996). The market for corporate control and firm innovation. Academy of Management Journal, 39, 1084-1119. http://dx.doi.org/10.2307/256993

Jackling, B. J., \& Johl, S. (2009). Board structure and firm performance: Evidence from India's top companies. Corporate Governance: An Review, $\quad$ International $492-509$. http://dx.doi.org/10.1111/j.1467-8683.2009.00760.x

Janis, I. L. (1972). Victims of Groupthink: A Psychological Study of Foreign-Policy Decisions and Fiascoes. Boston: Houghton Mifflin Company.

Jensen, M. C. (1993). The modern industrial revolution, exit, and the failure of internal control systems. Journal of Finance, 48, 831-880. http://dx.doi.org/10.1111/j.1540-6261.1993.tb04022.x

Johnson, S., \& Mitton, T. (2003). Cronyism and capital controls: Evidence from Malaysia. Journal of Financial Economics, 67, 351-382. http://dx.doi.org/10.1016/S0304-405X(02)00255-6

Kang, H., Cheng, M., \& Gray, S. J. (2007). Corporate governance and board composition: diversity and independence of Australian boards. Corporate Governance, 15, 194-207. http://dx.doi.org/10.1111/j.1467-8683.2007.00554.x 
Kang, J., \& Shivdasani, A. (1999). Alternative mechanisms for corporate governance in Japan: an analysis of independent and bank-affiliated firms. Pacific-Basin Finance Journal, 7, 1-22. http://dx.doi.org/10.1016/S0927-538X(98)00020-1

Kato, T., \& Long, C. (2006). CEO turnover, firm performance and enterprise reform in China: Evidence from micro data. Journal of Comparative Economics, 34, 796-817. http://dx.doi.org/10.1016/j.jce.2006.08.002

Kresner, I. (1988). Directors' characteristics and committee membership: An investigation of type, occupation, tenure, and gender. Academy of Management Journal, 31, 66-84. http://dx.doi.org/10.2307/256498

Krivogorsky, V. (2006). Ownership, board structure and performance in Continental Europe. The International Journal of Accounting, 41, 176-197. http://dx.doi.org/10.1016/j.intacc.2006.04.002

Lefort, F., \& Urzua, F. (2008). Board independence, firm performance and ownership concentration: Evidence from Chile. Journal of Business Research, 61, 615-622. http://dx.doi.org/10.1016/j.jbusres.2007.06.036

Li, J., Chu, W. L., Lam, C. K., \& Liao, S. (2011). Age diversity and firm performance in an emerging economy: Implications for cross-cultural human resource management. Human Resource Management, 50, 247-270. http://dx.doi.org/10.1002/hrm.20416

Lin, X., Zhang, Y., \& Zhu, N. (2009). Does bank ownership increase firm value? Evidence from China. Journal of International Money and Finance, 28, 720-737. http://dx.doi.org/10.1016/j.jimonfin.2008.12.015

Loderer, C., \& Waelchli, U. (2010). Firm age and performance. Working paper. University of Bern, Switzerland.

Malaysian Code on Corporate Governance, MCCG (Revised). (2007). Kuala Lumpur: Securities Commission.

Milliken, F., \& Martins, L. (1996). Searching for common threats: understanding the multiple effects of diversity in organisational groups. Academy of Management Review, 21, 402-433.

Mitchell, H., \& Joseph, S. (2010). Changes in Malaysia: Capital controls, prime ministers and political connections. Pacific-Basin Finance Journal, 18, 460-476. http://dx.doi.org/10.1016/j.pacfin.2010.05.002

Mohamad, S., Hassan, T., Nasir, A., \& Chen, C. M. (2007). Characteristics and performance of politically-linked firms in Malaysia. The International Journal of Finance, 19, 4576-4603.

Morbey, G. K. (1988). RandD: Its relationship to company performance. Journal of Product Innovation Management, 5, 191-200. http://dx.doi.org/10.1016/0737-6782(88)90022-7

Nicholson, G. J., \& Kiel, G. C. (2007). Can directors impact performance? A case-based test of three theories of corporate governance. Corporate Governance: An International Review, 15, 585-608. http://dx.doi.org/10.1111/j.1467-8683.2007.00590.x

Niessen, A., \& Ruenzi, S. (2010). Political connectedness and firm performance: Evidence from Germany. German Economic Review, 11, 441-464. http://dx.doi.org/10.1111/j.1468-0475.2009.00482.x

Olson, M. (1982). The rise and decline of nations. New Haven and London: Yale University Press.

Palepu, K. G. (1986). Predicting takeover targets: a methodological and empirical analysis. Journal of Accounting and Economics, 8, 3-35. http://dx.doi.org/10.1016/0165-4101(86)90008-X

Pfeffer, J., \& Salancik, G. (1978). The external control of organizations: A resource-Dependence perspective. New York: Harper and Row.

Poon, W. C. (2008). Malaysian Economy (2nd ed.). Selangor, Malaysia: Pearson Education, Prentice Hall.

Price, R., Roman, F. J., \& Rountree, B. (2011). The impact of governance reform on performance and transparency. Journal of Financial Economics, 99, 76-96. http://dx.doi.org/10.1016/j.jfineco.2010.08.005

Ramasamy, B., Ng, H. L., \& Hung, W. T. (2007). Corporate social performance and ethnicity: A comparison between Malay and Chinese chief executives in Malaysia. International Journal of Cross Cultural Management, 7, 29-45. http://dx.doi.org/10.1177/1470595807075169

Roberts, B. E. (1990). A dead senator tells no lies: seniority and the distribution of federal benefits. American Journal of Political Science, 34, 31-58. http://dx.doi.org/10.2307/2111510

Switzer, L. N. (2007). Corporate governance, Sarbanes-Oxley, and small-cap firm performance. The Quarterly Review of Economics and Finance, 47, 651-666. http://dx.doi.org/10.1016/j.qref.2007.08.001

Tajfel, H. and Turner, J.C. (1986). The social identity theory of intergroup behaviour. In Worchel, S. and Austin, W.G. (Eds.), Psychology of Intergroup Relations, 7-24. Chicago, IL: Nelson-Hall. 
Terjesen, S., Sealy, R., \& Singh, V. (2009). Women directors on corporate boards: A review and research agenda. $\begin{array}{lllll}\text { Corporate } \quad \text { Governance: An } & \text { International }\end{array}$ http://dx.doi.org/10.1111/j.1467-8683.2009.00742.x

Wallace, R. S., \& Cooke, T. E. (1990). The diagnosis and resolution of emerging issues in corporate disclosure $\begin{array}{llll}\text { practices. Accounting and Business } & \text { Research, }\end{array}$ http://dx.doi.org/10.1080/00014788.1990.9728872

Westphal, J. D., \& Zajac, E. (1995). Who shall govern? CEO, board power, demographic similarity and new director selection. Administrative Science Quarterly, 40, 60-83. http://dx.doi.org/10.2307/2393700

Yatim, P., Kent, P., \& Clarkson, P. (2006). Governance structures, ethnicity and audit fees of Malaysian listed firms. Managerial Auditing Journal, 21, 757-782. http://dx.doi.org/10.1108/02686900610680530

Yermack, D. (1996). Higher market valuation of companies with a small board of directors. Journal of Financial Economics, 40, 185-211. http://dx.doi.org/10.1016/0304-405X(95)00844-5

Yoshikawa, T., \& Phan, P. H. (2003). The performance implications of ownership-driven governance reform. European Management Journal, 21, 698-706. http://dx.doi.org/10.1016/j.emj.2003.09.013

Zahra, S. A., \& Stanton, W. W. (1988). The implications of board of directors' composition for corporate strategy and performance. International Journal of Management, 5, 229-236.

\section{Notes}

Note 1. Past studies used economic-based theories to investigate the association between board composition and firm performance in general (Anderson \& Gupta, 2009; Kato \& Long, 2006; Krivogorsky, 2006; Lefort \& Urzua, 2008; Price, Roman, \& Rountree, 2011; Switzer, 2007; Yoshikawa \& Phan, 2003), and between board composition-bank performance in particular (Berger \& Patti, 2006; Gorton \& Schmid, 1999; Kang \& Shivdasani, 1999; Lin, Zhang, \& Zhu, 2009).

Note 2. The Asian Financial Crisis caused liquidity and insolvency problems for banking industry following excessive deficient collateral property lending and inattentive exposure to share-based lending, leaving them burdened with high Non-Performing Loans (NPLs). BNM enforced a merging scheme with the objective to enhance shareholder value by reinforcing the efficiency and profitability of the financial institutions vis-a-vis to minimize post-integration costs. BNM announced on $29^{\text {th }}$ July, 1999 that the existing 55 financial institutions (i.e., 20 commercial banks, 23 finance companies, and 12 merchant banks) were to form six-anchor banking groups by the end of September 1999 (Poon, 2008). These six-anchor banks were nominated by the central bank and their selection was politically driven (Mitchell \& Joseph, 2010), and linked to allegations of cronyism (Chong, Liu, \& Tan, 2006). Some objections arose pertaining to the composition of the groups. The government responded by giving flexibility to the banking institutions to form their own merger groups and the number of groups rose from six to ten, and the merging exercise deadline was extended till the end of January 2000.

Note 3. The guideline for banking sector was published by Basel Committee (1999; 2006), and it lists the responsibility of BOD on operations and financial soundness of the banks. The independent director requirement was announced in 1998, and 1999 was the first year when such regulations were enforced. During the last decade, the government has introduced significant reforms in corporate governance, including the enactment of the revised Malaysian Code on Corporate Governance (MCCG) 2007 as the "Best Practice Guide" to promote transparency and encourage self-regulatory behavior among PLCs. "Best practice" advocates that the board composition should have a majority of independent non-executive directors (MCCG Revised 2007, p.11).

Note 4. There are nine domestic commercial banks in Malaysia in the post-merged era. There are seven firms in 2000, eight firms from 2001-2002, and nine firms from 2003-2009. 